\title{
An Easy Access to Two Epimeric $N$-Substituted (2S)-2-(2'-Hydroxypropyl)pyrrolidines
}

\author{
Maria Joselice e Silva ${ }^{a, b}$, Louis Cottier ${ }^{b}$, Rajendra M. Srivastava ${ }^{*, a}$ and Denis Sinou $^{b}$ \\ ${ }^{a}$ Departamento de Química Fundamental, Universidade Federal de Pernambuco, Cidade Universitária, 50.740-540 \\ Recife - PE, Brazil. \\ ${ }^{b}$ Laboratoire de Synthèse Asymétrique, associe au CNRS UMR 5181, ESCPE Lyon, Université Claude Bernard Lyon 1, \\ boulevard du 11 november 1918, 69622, Villeurbanne Cedex, France
}

\begin{abstract}
Uma fácil e eficiente síntese para obtenção de $\beta$-aminocetonas 5a, 6 e $\gamma$-aminoálcoois 1a, 2a, 3, 4 enantiomericamente puros a partir de L-prolinol 7 e L-prolina 15 é descrita. A etapa principal da reação foi o uso do reagente de Tebbe que permitiu a transformação da função éster a um enol éter que após hidrólise formou a cetona sem nenhuma racemização.

An easy and efficient route for the synthesis of enantiomerically pure $\beta$-aminoketones $\mathbf{5 a}, \mathbf{6}$ and $\gamma$-aminoalcohols 1a, 2a, 3, 4 from L-prolinol 7 and L-proline 15 is described. One of the key steps is the use of Tebbe's reagent allowing the transformation of the ester function to an enol ether without any racemization.
\end{abstract}

Keywords: $\beta$-aminoketones, $\gamma$-aminoalcohols, racemization, Tebbe's reagent

\section{Introduction}

In our ongoing research on the total synthesis of glycoheterocyclic compounds, we needed compounds $\left(2 S, 2^{\prime} R\right)$ - and $\left(2 S, 2^{\prime} S\right)-N$ - ( $p$-toluenesulfonyl)- and $\left(2 S, 2^{\prime} R\right)-$ and $\left(2 S, 2^{\prime} S\right)-N$-(methoxycarbonyl)-2-(2'hydroxypropyl)pyrrolidines 1a, 2a 3 and $\mathbf{4}$ respectively. Before starting the present work, we surveyed the literature and found no record of $N$-tosyl alcohols 1a and 2a.

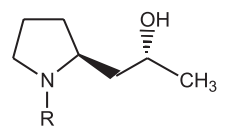

1a: $\mathrm{R}=\mathrm{Ts}$

3: $\mathrm{R}=\mathrm{CO}_{2} \mathrm{CH}_{3}$

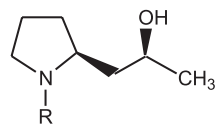

2a: $\mathrm{R}=\mathrm{Ts}$

4: $\mathrm{R}=\mathrm{CO}_{2} \mathrm{CH}_{3}$

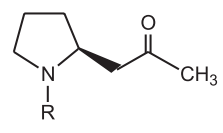

5a: $\mathrm{R}=\mathrm{Ts}$

6: $\mathrm{R}=\mathrm{CO}_{2} \mathrm{CH}_{3}$
There are entries for the racemic alcohols 3 and $\mathbf{4},{ }^{1,2}$ and also of enantiomerically pure $4 .^{3}$ Our interest developed knowing the fact that pyrrolidine derivatives possess biological activities. ${ }^{4,5}$

For obtaining the aforementioned alcohols, our first approach was to prepare ketones $\mathbf{5 a}$ and $\mathbf{6}$ in the enantiomerically pure forms. In fact racemic $\mathbf{5}$ was prepared earlier in four steps by a tandem $\mathrm{S}_{\mathrm{N}} 2$-Michael addition

* e-mail: rms@ufpe.br reaction without any description about their optical purity. ${ }^{6}$ Racemic $\mathbf{6}$ is also known. ${ }^{1}$ This contribution therefore gives a detailed account of acquiring compounds 1a, 2a, 3, 4, 5a and $\mathbf{6}$ starting from $(S)$-prolinol $\mathbf{7}$ or $(S)$-proline $\mathbf{1 5}$ (Schemes 1 and 3).

\section{Results and Discussion}

We envisaged the synthesis of ketone 5a starting from (S)-prolinol 7 involving a series of steps (Scheme 1). The use of Tebbe's reagent ${ }^{7}$ to transform $\mathbf{1 0} \rightarrow \mathbf{5 a}$ turned out to be interesting because this reagent is used in a non-basic medium. Thus, racemization does not take place on substrates with enolizable chiral centers or other base sensitive groups.

Initially, we decided to ditosylate compound $\mathbf{7}^{8}$ in order to obtain $\mathbf{8}$ and its transformation to nitrile $\mathbf{9 a} .^{8}$ The last product was converted to ester $\mathbf{1 0}$. Treatment of $\mathbf{1 0}$ with Tebbe's reagent and subsequent hydrolysis of enol ether led to ketone 5a which was reduced to $1 \mathbf{a}$ and $\mathbf{2 a}$ with sodium borohydride (Scheme 1).

The ${ }^{1} \mathrm{H}$ NMR spectra of 1a and 2a are consistent with the proposed structures. Compound 5a was found to be enantiomerically pure by ${ }^{1} \mathrm{H}$ NMR spectroscopy as verified by the chiral shift reagent, europium tris[3(heptafluoropropylhydroxymethylene)-(+)-camphorate. 


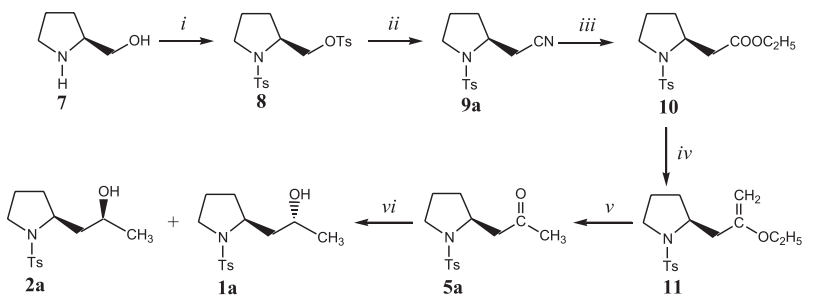

Scheme 1. $i$ : TsCl, Py, rt, 12h, 89\%; ii: NaCN, DMSO, rt, 72h, 90\%; iii: $\mathrm{EtOH}, \mathrm{HCl}(\mathrm{g}), \mathrm{rt}, 24 \mathrm{~h}, 60 \%$; iv: 1) Tebbe's reagent, THF, $0{ }^{\circ} \mathrm{C}$, $30 \mathrm{~min}$; 2) $\mathrm{Et}_{2} \mathrm{O}, \mathrm{NaOH} 0.1 \mathrm{~mol} \mathrm{~L}-1$; $v$ : $\mathrm{HCl} 2 \mathrm{~mol} \mathrm{~L}^{-1}, \mathrm{CHCl}_{3}, \mathrm{rt}, 1.5 \mathrm{~h}$, $79 \%$ from 10; vi: $\mathrm{NaBH}_{4}, \mathrm{MeOH}, 0{ }^{\circ} \mathrm{C}, 1 \mathrm{~h}, 96 \%$ (1a:2a, 2.0:1.0).

The same chiral shift reagent was used for obtaining the ${ }^{1} \mathrm{H}$ NMR spectrum of the racemic mixture $\mathbf{5 a}, \mathbf{5 b}$.

It is well known that $N$-alkyl $\beta$-amino ketones racemize rapidly in basic medium ${ }^{9}$ and the cleavage of the pyrrolidine ring is favored when the nitrogen atom carries an electron withdrawing group. ${ }^{10,11}$ Before the synthesis of 5a employing Tebbe's reagent, we also visualized to prepare ketone $\mathbf{5 a}$ in basic medium. For this, compound 9a was allowed to react with MeLi which furnished $\mathbf{5 a}, \mathbf{5 b}$ with $54 \%$ enantiomeric excess in favor of the $(S)$ configuration. The ee was determined by measuring the optical rotation of the mixture $\mathbf{5 a}, \mathbf{5 b}$ and comparing with the value of the pure enantiomer $\mathbf{5 a}$. Next, we attempted to obtain $5 \mathbf{a}$ from $\mathbf{1 4}$ using acidic conditions. ${ }^{12}$ This provided racemic 5a,5b, which after reduction with sodium borohydride yielded a mixture of stereoisomers, viz., 1a, $\mathbf{1 b}$ and 2a, 2b, respectively (Scheme 2). Each enantiomeric pair was separated by liquid chromatography over silica gel in the ratio of 2.1:1.0 (1a, $\mathbf{1} \mathbf{b}: \mathbf{2} \mathbf{a}, \mathbf{2} \mathbf{b})$; the fast moving spot $\mathbf{2 a}, \mathbf{2} \mathbf{b}$ crystallized and its X-ray analysis showed them as a racemic mixture consisting of enantiomers $\left(2 S, 2^{\prime} S\right)$ 2a and its mirror image $\left(2 R, 2^{\prime} R\right) \mathbf{2 b}$. Since the racemic mixture gave beautiful crystals suitable for X-ray data collection, we analysed it crystallographically. The X-ray structure is depicted in Figure 1.

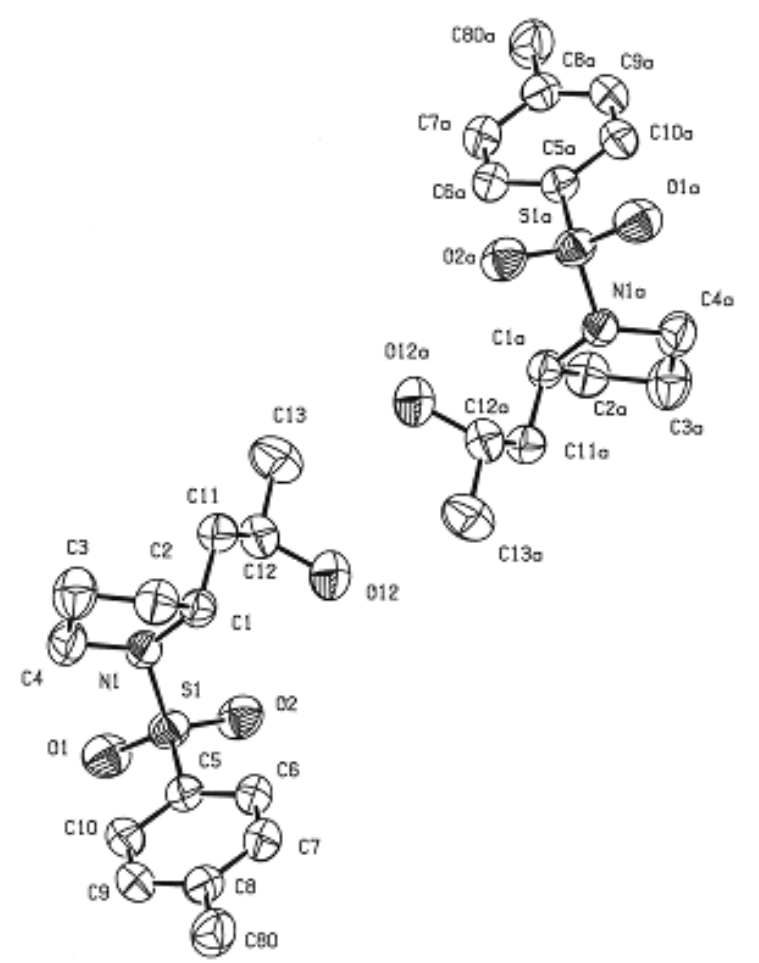

Figure 1. X-ray crystal structures presenting the enantiomeric mixture of $\left(2 S, 2^{\prime} S\right)$ - and $\left(2 R, 2^{\prime} R\right)-N$-( $p$-toluenesulfonyl)-2-pyrrolidinyl-2-propanols $\mathbf{2 a}, \mathbf{2 b}$.

The single crystal structure analysis shows that the pyrrolidine ring is somewhat deviated and not in an envelope shape. The torsion angles $\mathrm{C}(4)-\mathrm{N}(1)-\mathrm{C}(1)-\mathrm{C}(2)$, $\mathrm{N}(1)-\mathrm{C}(1)-\mathrm{C}(2)-\mathrm{C}(3)$ and $\mathrm{C}(2)-\mathrm{C}(3)-\mathrm{C}(4)-\mathrm{N}(1)$ are -19.7, 34.2 and 24.4 degrees, respectively. It further provides the bond angles $\mathrm{C}(4)-\mathrm{N}(1)-\mathrm{S}(1)$ and $\mathrm{C}(1)-\mathrm{N}(1)-\mathrm{S}(1)$ of 118.7 and 118.8 degrees which is very close to 120 degrees indicating $s p^{2}$ hybridization of the nitrogen atom. The N-S bond distance found in the current work is $1.622 \AA$, both $\mathrm{S}=\mathrm{O}$ bond distances are: 1.431 and 1.434 ,

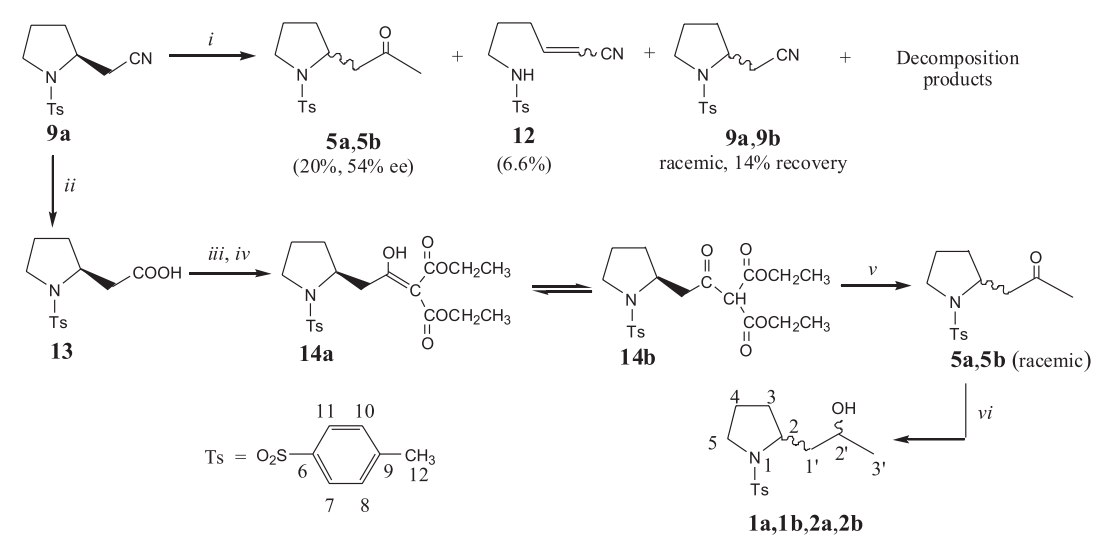

Scheme 2. $i$ : 1) MeLi, THF, $0{ }^{\circ} \mathrm{C}, 1 \mathrm{~h}$; 2) $\mathrm{Aq} \mathrm{HCl}$; $i$ : $\mathrm{AcOH}, 37 \% \mathrm{HCl}, 100{ }^{\circ} \mathrm{C}, 4 \mathrm{~h}, 66 \%$; iii: $(\mathrm{COCl})_{2}, \mathrm{DMF}_{2} \mathrm{CH}_{2} \mathrm{Cl}_{2}, \mathrm{rt}, 4 \mathrm{~h} ; i v: \mathrm{NaH}_{2} \mathrm{CH}_{2}\left(\mathrm{CO}_{2} \mathrm{CH}_{2} \mathrm{CH}_{3}\right)_{2}$, THF, $\Delta, 3 \mathrm{~h}, 78 \%$; $v: \mathrm{H}_{2} \mathrm{SO}_{4} 4 \mathrm{~mol} \mathrm{~L}-1,100{ }^{\circ} \mathrm{C}, 12 \mathrm{~h}, 79 \%$. vi: $\mathrm{NaBH}_{4}, \mathrm{MeOH}, 0{ }^{\circ} \mathrm{C}, 1 \mathrm{~h}, 96 \%(\mathbf{1 a}, \mathbf{1 b}: \mathbf{2 a}, 2 \mathbf{b}, 2.1: 1.0)$. 
respectively. These values are very close to the data reported in the literature for $\mathrm{N}$-tosyl-8-azaspiro(4,5)-deca1,3-diene, which have $\mathrm{N}-\mathrm{S}=1.631 ; \mathrm{S}=\mathrm{O}=1.446 ; \mathrm{S}=\mathrm{O}=$ $1.417 \AA$, respectively. ${ }^{13}$ Another interesting observation was found. The dihedral angles $\mathrm{N}(1)-\mathrm{S}(1)-\mathrm{C}(5)-\mathrm{C}(6)$ and $\mathrm{N}(1)-\mathrm{S}(1)-\mathrm{C}(5)-\mathrm{C}(10)$ are 85.2 and -90.5 degrees showing that the $p$-tolyl ring is almost perpendicular to $\mathrm{N}(1)-\mathrm{S}(1)$ bond. Other bond distances and bond angles observed are normal. Both $(R)$ and $(S)$ configurations of $\mathbf{2}$ can be visualized easily in the diagram (Figure 1).

Next, an alternative route for the synthesis of the known compounds $\mathbf{3}$ and $\mathbf{4}$ has been developed by us starting from $\mathrm{N}$-methoxycarbonyl-(S)-proline $\mathbf{1 6},{ }^{14}$ which in turn was obtained from $(S)$-proline 15. Homologation of $\mathbf{1 6}$ by ArndtEistert method $^{15}$ gave $\mathbf{1 7}$ which was converted to ester $\mathbf{1 8 .}$ The conversion of ester 18 to vinyl ether 19 utilizing Tebbe's reagent, followed by an acidic hydrolysis gave ketone $\mathbf{6}$ in an excellent yield. Sodium borohydride reduction of $\mathbf{6}$ afforded $\mathbf{3}$ and $\mathbf{4}$ in the ratio of 2.0:1.0 (Scheme 3). Alcohols 3 and $\mathbf{4}$ were separated in their pure forms by liquid chromatography over silica gel. Their structures and configurations agreed with the data reported earlier. ${ }^{1-3}$

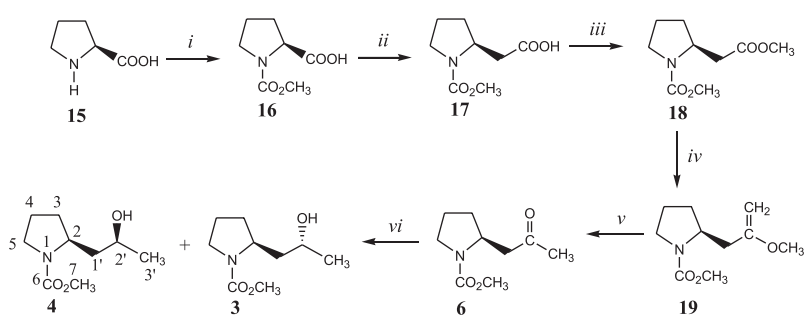

Scheme 3. $i$ : $\mathrm{CH}_{3} \mathrm{OCOCl}, \mathrm{NaHCO}_{3}$, THF, rt, 16h, 80\%; ii: 1) (COCl), DMF, $\mathrm{CH}_{2} \mathrm{Cl}_{2}, 0{ }^{\circ} \mathrm{C}-\mathrm{rt}, 4 \mathrm{~h}$; 2) $\mathrm{CH}_{2} \mathrm{~N}_{2}, \mathrm{Et}_{2} \mathrm{O}, 0{ }^{\circ} \mathrm{C}, 5 \mathrm{~h}$; 3) $\mathrm{Ag}_{2} \mathrm{O}, \mathrm{H}_{2} \mathrm{O}$, dioxane, $90{ }^{\circ} \mathrm{C}, 6 \mathrm{~h}, 46 \%$; iii: $\mathrm{CH}_{2} \mathrm{~N}_{2}, \mathrm{Et}_{2} \mathrm{O}, 0{ }^{\circ} \mathrm{C}, 1 \mathrm{~h}, 100 \%$; iv: 1 ) Tebbe's reagent, THF, $\left.0{ }^{\circ} \mathrm{C}, 30 \mathrm{~min} ; 2\right) \mathrm{Et}_{2} \mathrm{O}, \mathrm{NaOH} 0.1 \mathrm{~mol} \mathrm{~L}^{-1}$; v: $\mathrm{HCl} 1 \mathrm{~mol} \mathrm{~L}^{-1}, \mathrm{CHCl}_{3}, \mathrm{rt}, 1.5 \mathrm{~h}, 83 \%$ from 18; vi: $\mathrm{NaBH}_{4}, \mathrm{MeOH}$, $0{ }^{\circ} \mathrm{C}, 1 \mathrm{~h}, 90 \%(\mathbf{3 : 4}, 2.0: 1.0)$.

\section{Conclusion}

In conclusion, we have been able to synthesize ketones 5a and $\mathbf{6}$ without any epimerization using Tebbe's reagent and also the known diastereoisomers 3 and $\mathbf{4}$ by an alternative route not elaborated previously. Compounds 6 and $\mathbf{4}$ may be considered as precursors of (-)-hygrine and (-)-hygroline, ${ }^{1-3}$ which are natural alkaloids. A new synthetic procedure has been developed for alcohols $\mathbf{1 a}$, racmic $\mathbf{1 a}, \mathbf{1 b}$, 2a and racemic 2a,2b starting from (S)-prolinol $\mathbf{7}$.

\section{Experimental}

Melting points were determined on an Electrothermal digital melting points apparatus (model IA9100) and are uncorrected. Specific rotations were measured on a PerkinElmer polarimeter model 241. NMR spectra were recorded with a Bruker AM $300 \mathrm{MHz}$ for $\mathrm{NMR}{ }^{1} \mathrm{H}$ and $75.5 \mathrm{MHz}$ for NMR ${ }^{13} \mathrm{C}$ using TMS as an internal standard. Chemical shifts $(\delta)$ are expressed as ppm and splitting patterns are designated as: $\mathrm{s}=$ singlet, $\mathrm{bs}=$ broad singlet, $\mathrm{d}=$ doublet, $\mathrm{dd}=$ double doublet, $\mathrm{t}=$ triplet, $\mathrm{q}=$ quartet and $\mathrm{m}=$ multiplet. Silica gel 60 (230 - 400 mesh) was employed for liquid chromatography. Petroleum ether used in the experiments had boiling range of $40-65^{\circ} \mathrm{C}$.

Ethyl (-)-(S)- $N$-(p-toluenesulfonyl)-2-pyrrolidinyl acetate (10). (-)-(S)-N-(p-Toluenesulfonyl)-2-pyrrolidinyl acetonitrile $9 \mathrm{a}(1.0 \mathrm{~g}, 3.79 \mathrm{mmol})$ in absolute ethanol (40.0 $\mathrm{mL}$ ) saturated with gaseous $\mathrm{HCl}$ was stirred for $24 \mathrm{~h}$ at room temperature. Solvent removal under reduced pressure, dissolution of the residue in ice-cold water followed by the treatment with $\mathrm{NaHCO}_{3}$ furnished an alkaline solution with a $\mathrm{pH}$ value of $\sim 9$ 9.0. Extraction with $\mathrm{CH}_{2} \mathrm{Cl}_{2}$, drying $\left(\mathrm{Na}_{2} \mathrm{SO}_{4}\right)$, filtration and solvent removal left an oil. Liquid chromatography of this material over silica gel using a mixture of petroleum ether and diethyl ether (1:1) gave $0.71 \mathrm{~g}(60 \%)$ of the chromatographically pure product as solid having $R_{f}$ value of 0.5 (petroleum ether:diethyl ether, 1:1). $[\alpha]_{\mathrm{D}}^{25}-103.2\left(c 1.04, \mathrm{CH}_{2} \mathrm{Cl}_{2}\right) . \mathrm{IR}(\mathrm{KBr}) v_{\max } / \mathrm{cm}^{-1}: 1735$ ( $v \mathrm{C}=\mathrm{O}), 1250$ and 1050 ( $v \mathrm{C}-\mathrm{O}) .{ }^{1} \mathrm{H}$ NMR (300 MHz, $\mathrm{CDCl}_{3}$ ): $\delta 1.27\left(\mathrm{t}, 3 \mathrm{H}, J 7.1 \mathrm{~Hz}\right.$, aliph.- $\left.\mathrm{CH}_{3}\right), 1.51-1.90(\mathrm{~m}$, 4H, H-3, H-4), 2.44 (s, 3H, H-12), 2.53 (dd, 1H, J $10.1 \mathrm{~Hz}, J$ $16.0 \mathrm{~Hz}, \mathrm{H}-1^{\prime}$ ), 3.10 (dd, 1H, J $3.9 \mathrm{~Hz}, J 16.0 \mathrm{~Hz}, \mathrm{H}-1^{\prime}$ ), 3.11-3.17 (m, 1H, H-5), 3.41-3.48 (m, 1H, H-5), 3.93-3.99 (m, 1H, H-2), 4.14 (2q overlapping, $2 \mathrm{H}, J 7.1 \mathrm{~Hz},-\mathrm{OCH}_{2}$ ) 7.32 (d, 2H, J $8.2 \mathrm{~Hz}, \mathrm{H}-8, \mathrm{H}-10), 7.76$ (d, 2H, J 8.2 Hz, H7, H-11). ${ }^{13} \mathrm{C}$ NMR $\left(75.5 \mathrm{MHz}, \mathrm{CDCl}_{3}\right): \delta 14.5$ (aliph.$\left.\mathrm{CH}_{3}\right), 21.8$ (C-12), 24.1 (C-4), 32.0 (C-3), 41.7 (C-5), 49.5 (C-1'), 56.9 (C-2), 60.8 (- $\left.\mathrm{OCH}_{2}-\right), 127.9$ (C-8, C-10), 130.1 (C-7, C-11), 134.4 (C-9), 143.9 (C-6), 171.6 (CO). The NMR spectra agreed with the literature data. ${ }^{6}$

(-)-(S)-N-(p-Toluenesulfonyl)-2-pyrrolidinyl propanone $(5 a)$. Tebbe's reagent $\left(2.0 \mathrm{~mL}, 0.5 \mathrm{~mol} \mathrm{~L}^{-1}\right.$ in toluene) was added to ester 10 ( $0.31 \mathrm{~g}, 1.0 \mathrm{mmol})$ dissolved in THF (3.0 $\mathrm{mL}$ ) at $0{ }^{\circ} \mathrm{C}$, and the mixture was stirred for $30 \mathrm{~min}$ at room temperature. Soon after, ether $(15.0 \mathrm{~mL})$ and seven drops of $0.1 \mathrm{~mol} \mathrm{~L}^{-1} \mathrm{NaOH}$ was added to it and stirred for an additional $30 \mathrm{~min}$. Solvent drying over $\mathrm{Na}_{2} \mathrm{SO}_{4}$, filtration over celite and solvent evaporation under vacuum left the crude product. This was then dissolved in $\mathrm{CHCl}_{3}(15.0$ $\mathrm{mL}$ ) and six drops of a $2.0 \mathrm{~mol} \mathrm{~L}^{-1} \mathrm{HCl}$ added to it followed by stirring for $1.5 \mathrm{~h}$ at room temperature. Water was added $(30.0 \mathrm{~mL})$ to the solution followed by neutralization with 
$\mathrm{NaHCO}_{3}$. Extraction with $\mathrm{CH}_{2} \mathrm{Cl}_{2}(3$ x $30.0 \mathrm{~mL})$, drying $\left(\mathrm{Na}_{2} \mathrm{SO}_{4}\right)$, filtration and solvent removal provided the crude solid (0.28 g). Column chromatography over silica gel using petroleum ether and ethyl acetate (6:4) gave pure 5a which yielded colorless crystals $(0.22 \mathrm{~g}, 79 \%)$ after crystallization from petroleum ether-dichloromethane, $\mathrm{mp}$. 94-96 ${ }^{\circ} \mathrm{C},[\alpha]_{\mathrm{D}}{ }^{25}-116.9\left(c 1, \mathrm{CH}_{2} \mathrm{Cl}_{2}\right)$. ${ }^{1} \mathrm{H} \mathrm{NMR}(300 \mathrm{MHz}$, $\left.\mathrm{CDCl}_{3}\right): \delta 1.43-1.61$ (m, 2H, H-4), 1.72-1.82 (m, 2H, H-3), 2.17 (s, 3H, H-3'), 2.43 (s, 3H, H-12), 2.65 (dd, 1H, J9.7 Hz, $J 17.8$ Hz, H-1'), 3.04-3.12 (m, 1H, H-5), 3.25 (dd, 1H, J 3.2 $\mathrm{Hz}, J 17.8$ Hz, H-1' ), 3.40-3.47 (m, 1H, H-5), 3.89-3.94 (m, 1H, H-2), 7.33 (d, 2H, J 7.9 Hz, H-8, H-10), 7.72 (d, 2H, J $8.2 \mathrm{~Hz}, \mathrm{H}-7, \mathrm{H}-11) .{ }^{13} \mathrm{C} \mathrm{NMR}\left(75.5 \mathrm{MHz}, \mathrm{CDCl}_{3}\right): \delta 21.9$ (C-12), 24.1 (C-4), 30.9 (C-3'), 32.4 (C-3), 49.5 (C-5), 51.0 (C-1'), 56.2 (C-2), 128.0 (C-8, C-10), 130.1 (C-7, C-11), 134.0 (C-9), 143.9 (C-6), 207.5 (C-2'). The NMR spectra agreed with the literature data. ${ }^{6}$

$N$-(p-Toluenesulfonyl)-2-pyrrolidinyl propanol-2 (1a and $2 a$ ). Sodium borohydride $(27 \mathrm{mg}, 0.71 \mathrm{mmol})$ was added at $0{ }^{\circ} \mathrm{C}$ to compound $\mathbf{5 a}(0.1 \mathrm{~g}, 0.36 \mathrm{mmol})$ dissolved in methanol $(8.0 \mathrm{~mL})$ and the contents stirred for $1 \mathrm{~h}$ at this temperature. After this, a $2.0 \mathrm{~mol} \mathrm{~L}^{-1} \mathrm{HCl}(0.5 \mathrm{~mL})$ was added to the solution and stirred for additional $10 \mathrm{~min}$. Neutralization of this solution with aqueous $\mathrm{NaHCO}_{3}$, extraction with $\mathrm{CH}_{2} \mathrm{Cl}_{2}$ and work-up yielded two diastereoisomers which were separated by column chromatography over silica gel using petroleum ether and ethyl acetate (1.5:1.0) to give 1a $(66.0 \mathrm{mg})$ and $\mathbf{2 a}(31.0$ $\mathrm{mg})(2.1: 1.0)$. The combined yield was $96 \%$. These compounds were recrystallized from hexane and ethyl acetate (5:1). Compound 1a: mp. 84-85 ${ }^{\circ} \mathrm{C},[\alpha]_{\mathrm{D}}{ }^{25}-98.0(c$ 1.04, $\mathrm{CH}_{2} \mathrm{Cl}_{2}$ ), $R_{f} 0.4$ (petroleum ether:EtOAc, 6:4). Anal. Calc. for $\mathrm{C}_{14} \mathrm{H}_{21} \mathrm{NO}_{3} \mathrm{~S}$ : C, 59.33; H, 7.47. Found: C, 59.26; $\mathrm{H}, 7.31 .{ }^{1} \mathrm{H}$ NMR $\left(300 \mathrm{MHz}, \mathrm{CDCl}_{3}\right): \delta 1.26(\mathrm{~d}, 3 \mathrm{H}, J 6.2$ Hz, H-3'), 1.44-2.03 (m, 6H, H-1', H-3, H-4), 2.42 (s, 3H, H12), 3.14-3.22 (m, 1H, H-5), 3.37-3.45 (m, 1H, H-5), 3.853.93 (m, 2H, H-2, H-2') 7.33 (d, 2H, J 8.1 Hz, H-8, H-10), 7.73 (d, 2H, $J 8.2 \mathrm{~Hz}, \mathrm{H}-7, \mathrm{H}-11) .{ }^{13} \mathrm{C} \mathrm{NMR}(75.5 \mathrm{MHz}$, $\left.\mathrm{CDCl}_{3}\right): \delta 21.9(\mathrm{C}-12), 24.3(\mathrm{C}-4), 24.7$ (C-3'), $31.6(\mathrm{C}-3)$, $46.4\left(\mathrm{C}^{-1}{ }^{\prime}\right), 49.2$ (C-5), 58.5 (C-2), $66.6\left(\mathrm{C}-2^{\prime}\right), 128.0$ (C-8, C-10), 130.0 (C-7, C-11), 134.8 (C-9), 143.8 (C-6). Compound 2a: mp. 92.5-94 ${ }^{\circ} \mathrm{C},[\alpha]_{\mathrm{D}}{ }^{25}-20.5$ (c 0.83 , $\mathrm{CH}_{2} \mathrm{Cl}_{2}$ ), $R_{f} 0.5$ (petroleum ether:EtOAc, 6:4). Anal. Calc. for $\mathrm{C}_{14} \mathrm{H}_{21} \mathrm{NO}_{3} \mathrm{~S}$ : C, 59.33; H, 7.47. Found: C, 59.69; H, 7.72. ${ }^{1} \mathrm{H}$ NMR $\left(300 \mathrm{MHz}, \mathrm{CDCl}_{3}\right): \delta 1.23(\mathrm{~d}, 3 \mathrm{H}, J 6.4 \mathrm{~Hz}$, H-3'), 1.31-1.88 (m, 6H, H-1', H-3, H-4), 2.43 (s, 3H, H-12), 3.13-3.22 (m, 1H, H-5), 3.34-3.42 (m, 1H, H-5), 3.46 (bs, $1 \mathrm{H}, \mathrm{OH}), 4.02-4.10$ (m, 1H, H-2), 4.16-4.20 (m, 1H, H-2'), 7.33 (d, 2H, J 8.1 Hz, H-8, H-10), 7.73 (d, 2H, J 8.2 Hz, H7, H-11). ${ }^{13} \mathrm{C} \mathrm{NMR} \mathrm{(75.5} \mathrm{MHz,} \mathrm{CDCl}_{3}$ ): $\delta 21.9$ (C-12), 23.2
(C-3'), 24.4 (C-4), 31.7 (C-3), 45.8 (C-1' ), 48.8 (C-5), 58.1 (C-2), 64.1 (C-2'), 127.9 (C-8, C-10), 130.1 (C-7, C-11), 134.7 (C-9), 144.1 (C-6).

$N$-(p-Toluenesulfonyl)-2-pyrrolidinyl propanone $(5 \boldsymbol{a}, \mathbf{5} \boldsymbol{b})$. To a solution of (-)-(S)-N-(p-toluenesulfonyl)-2pyrrolidinyl acetonitrile 9a $(1.0 \mathrm{~g}, 3.79 \mathrm{mmol})$ in dry THF (26.0 mL) at $0{ }^{\circ} \mathrm{C}$, was added $0.75 \mathrm{~mol} \mathrm{~L}^{-1} \mathrm{MeLi}$ (1 equiv., $5.0 \mathrm{~mL}$ ) very slowly for $1 \mathrm{~h}$ under stirring. After this an aqueous solution of $1 \mathrm{~mol} \mathrm{~L}^{-1} \mathrm{HCl}$ was added at the same temperature and stirred for $3 \mathrm{~h}$ at $\mathrm{rt}$. The mixture was neutralized with $\mathrm{NaHCO}_{3}$, extracted with $\mathrm{CH}_{2} \mathrm{Cl}_{2}$ and dried $\left(\mathrm{Na}_{2} \mathrm{SO}_{4}\right)$. Purification by column chromatography over silica gel using $\mathrm{CH}_{2} \mathrm{Cl}_{2}$ gave $\mathbf{5 a}, \mathbf{5 b}(0.213 \mathrm{~g}, 20 \%)$. $[\alpha]_{\mathrm{D}}{ }^{25}$ 63.1 ( $c$ 1.03, $\mathrm{CH}_{2} \mathrm{Cl}_{2}$ ), ee 54\%. The NMR spectra of $\mathbf{5 a}, \mathbf{5 b}$ agreed with the literature data. ${ }^{6}$ Racemic 9a,9b was recovered $(0.14 \mathrm{~g}),[\alpha]_{\mathrm{D}}{ }^{25} 0\left(c 1, \mathrm{CHCl}_{3}\right)$. Data for 12: oil, $66.5 \mathrm{mg}$ (6.6\%), $R_{f} 0.32$ (petroleum ether:EtOAc, 7:3), IR(film) $v_{\max } / \mathrm{cm}^{-1}: 2220(v \mathrm{CN}) .{ }^{1} \mathrm{H}$ NMR $(300 \mathrm{MHz}$, $\left.\mathrm{CDCl}_{3}\right): \delta 1.71(\mathrm{~m}, 2 \mathrm{H}, \mathrm{H}-2), 2.28(\mathrm{~m}, 1 \mathrm{H}, \mathrm{H}-3), 2.38(\mathrm{~m}$, 1H, H-3), 2.40 (s, 3H, H-13), 2.98 (m, 2H, H-1), 5.34 (m, 2H, NH, H-4), 6.64 (m, 1H, H-5), 7.33 (d, 2H, J 7.9Hz, H-9, H11), 7.76 (d, 2H, J 7.2Hz, H-8, H-12). ${ }^{13} \mathrm{C} \mathrm{NMR}(75.5 \mathrm{MHz}$, $\mathrm{CDCl}_{3}$ ): $\delta 21.9$ (C-13), 27.9 (C-2), 30.3 (C-3), 42.7 (C-1), 101.0 (C-4), 117.6 (C-6), 127.4 (C-9, C-11), 130.2 (C-8, C12), 137.0 (C-10), 144.0 (C-7), 154.7 (C-5).

(-)-N-(p-Toluenesulfonyl)-2-pyrrolidinyl acetyl diethylmalonate (14). To (-)-(S)-N-(p-toluenesulfonyl)-2pyrrolidinyl acetic acid 13 (1.0 g, $3.53 \mathrm{mmol})$ in dichloromethane $(10.0 \mathrm{~mL})$ was added two drops of DMF and oxalyl chloride $(0.5 \mathrm{~mL}, \sim 1.5$ equiv. $)$ at $0{ }^{\circ} \mathrm{C}$. The mixture was stirred for $4 \mathrm{~h}$ at room temperature and concentrated to dryness. Diethylmalonate $(2.7 \mathrm{~mL}, 17.66 \mathrm{mmol})$ and $60 \%$ $\mathrm{NaH}(0.70 \mathrm{~g}, 17.66 \mathrm{mmol})$ in dry THF $(10.0 \mathrm{~mL})$ were stirred for $30 \mathrm{~min}$ at room temperature. Addition of the generated acid chloride in dry THF $(15.0 \mathrm{~mL})$ to this malonate suspension followed by stirring for $4 \mathrm{~h}$ at $70{ }^{\circ} \mathrm{C}$ completed the reaction. Addition of water, extraction with dichloromethane, drying the solution over $\mathrm{Na}_{2} \mathrm{SO}_{4}$ and solvent removal provided the crude product. Purification by column chromatography over silica gel using 4:1 petroleum ether:EtOAc gave $1.17 \mathrm{~g}(78 \%)$ of an oil caracterized as a 1:1 keto-enolic mixture of 14: TLC (petroleum ether:EtOAc, 4:1): $R_{f} 0.54 ;[\alpha]_{\mathrm{D}}{ }^{25}-101.8(c 1.05$, $\mathrm{CH}_{2} \mathrm{Cl}_{2}$ ). ${ }^{1} \mathrm{H}$ NMR $\left(300 \mathrm{MHz}, \mathrm{CDCl}_{3}\right): \delta$ 1.28-1.34 $(4 \mathrm{t}$ overlapping, $6 \mathrm{H}, J 6.9 \mathrm{~Hz}$, aliph.- $\left.\mathrm{CH}_{3}\right), 1.45-1.83$ (m, 4H, H-3, H-4), 2.43 (s, 1.5H, H-12), 2.44 (s, 1.5H, H-12), 2.66 (dd, 0.5H, J 10.0 Hz, J 13.7 Hz, H-1' ), 3.01 (dd, 0.5H, J9.8 Hz, J 18.2 Hz, H-1'), 3.03-3.10 (m, 1H, H-5), 3.18 (dd, $0.5 \mathrm{H}, J 4.5 \mathrm{~Hz}, J 13.7 \mathrm{~Hz}, \mathrm{H}^{-1}{ }^{\prime}$ ), 3.39 (dd, 0.5H, J 3.1 Hz, J 
18.2 Hz, H-1'), 3.41-3.49 (m, 1H, H-5), 3.94-4.01 (m, 1H, H-2), 4.29 (q, 4H, J 7.1 Hz, - $\mathrm{OCH}_{2}-$ ), 4.50 (s, 0.5H, H-3'), 7.33 (d, 2H, J 7.9 Hz, H-8, H-10), 7.76 (d, 2H, J 8.2 Hz, H7, H-11), 13.25 (s, 0.5H, OH). Anal. Calc. for $\mathrm{C}_{20} \mathrm{H}_{27} \mathrm{NO}_{5} \mathrm{~S} .1 / 4 \mathrm{H}_{2} \mathrm{O}: \mathrm{C}, 55.86 ; \mathrm{H}, 6.44$. Found: C, 55.91; $\mathrm{H}$, 6.41 .

$N$-(p-Toluenesulfonyl)-2-pyrrolidinyl propanone $(5 \boldsymbol{a}, \mathbf{5} \boldsymbol{b})$. (-)- $N$-( $p$-toluenesulfonyl)-2-pyrrolidinyl acetyl diethylmalonate $14(1.10 \mathrm{~g}, 2.59 \mathrm{mmol})$ in $4 \mathrm{~mol} \mathrm{~L} \mathrm{H} \mathrm{SO}_{4}$ $(55.0 \mathrm{~mL})$ was stirred for $12 \mathrm{~h}$ at $100{ }^{\circ} \mathrm{C}$. The mixture was neutralized with sat. aq. $\mathrm{NaHCO}_{3}$ and extracted with $\mathrm{CH}_{2} \mathrm{Cl}_{2}$. The extract was washed with water $(3 \times 100 \mathrm{~mL})$, dried $\left(\mathrm{Na}_{2} \mathrm{SO}_{4}\right)$ and concentrated to yield the crude product. Purification by column chromatography over silica gel using petroleum ether:EtOAc (7:3) gave 5a,5b which after crystallization from petroleum ether: $\mathrm{CH}_{2} \mathrm{Cl}_{2}$ yielded colorless crystals $(575 \mathrm{mg}, 79 \%):[\alpha]_{\mathrm{D}}{ }^{25} \mathrm{O}\left(\mathrm{c} 1, \mathrm{CH}_{2} \mathrm{Cl}_{2}\right)$. The NMR spectra agreed with the literature data. ${ }^{6}$

$N$-(p-Toluenesulfonyl)-2-pyrrolidinyl propanol-2 (1a, $\mathbf{1 b}$ and $\mathbf{2 a}, \mathbf{2 b}$ ). Starting from ketone $\mathbf{5 a}, \mathbf{5} \mathbf{b}$ and following the procedure described above, we obtained 1a,1b and 2a,2b (2.1:1). Yield 96\%. Compound 1a,1b: mp. $76-78^{\circ} \mathrm{C}$, $[\alpha]_{\mathrm{D}}{ }^{25} \mathrm{O}\left(\mathrm{c} 1.05, \mathrm{CH}_{2} \mathrm{Cl}_{2}\right)$. Compound $\mathbf{2 a}, \mathbf{2 b}: \mathrm{mp} \cdot 87-89^{\circ} \mathrm{C}$, $[\alpha]_{\mathrm{D}}{ }^{25} \mathrm{O}\left(\mathrm{c} 1, \mathrm{CH}_{2} \mathrm{Cl}_{2}\right)$. The ${ }^{1} \mathrm{H} \mathrm{NMR}$ and ${ }^{13} \mathrm{C}$ NMR spectra agreed with the compounds $\mathbf{1 a}$ and $\mathbf{2 a}$ above.

(-)-(S)-N-Methoxycarbonyl-L-proline (16). L-proline $15(1.0 \mathrm{~g}, 8.7 \mathrm{mmol})$ in THF $(15.0 \mathrm{~mL})$ was put in a roundbottom flask at $0{ }^{\circ} \mathrm{C}$ and $\mathrm{NaHCO}_{3}(3.65 \mathrm{~g})$ in water (4.0 $\mathrm{mL})$ was added to it. Afterwards, methyl chloroformate (3.4 mL, $43.5 \mathrm{mmol}$ ) was poured into the flask and the contents stirred for $16 \mathrm{~h}$ at room temperature. Acidification of the solution with dilute $\mathrm{HCl}$, extraction with $\mathrm{CH}_{2} \mathrm{Cl}_{2}$ and usual work-up gave the crude product which could be purified by column chromatography over silica using $\mathrm{CH}_{2} \mathrm{Cl}_{2}$ and ethyl acetate (1:1) as eluent. The work-up yielded $16(1.2 \mathrm{~g}, 80 \%)$ as light yellow oil. $[\alpha]_{\mathrm{D}}{ }^{25}-100.4$ (c 1.16, $\left.\mathrm{CH}_{2} \mathrm{Cl}_{2}\right)$. ${ }^{1} \mathrm{H} \mathrm{NMR}\left(300 \mathrm{MHz}, \mathrm{CDCl}_{3}\right): \delta 2.10(\mathrm{~m}$, 2H, H-4), 2.31 (m, 2H, H-3), 3.60 (m, 2H, H-5), 3.69, 3.74 (2s, 3H, H-7), 4.42 (m, 1H, H-2), 10.29 (s, 1H, OH). ${ }^{13} \mathrm{C}$ NMR (75.5 MHz, $\left.\mathrm{CDCl}_{3}\right): \delta 23.7,24.6(\mathrm{C}-4), 29.9,31.2$ (C-3), 46.8, 47.2 (C-5), 53.2, 53.3 (C-7), 59.0, 59.5 (C-2), 155.7, 156.6 (C-6), 176.9, 177.9 (C-1'). Certain proton and carbon atoms of this compound produced two signals because of the existence of two rotamers at room temperature.

(S)-N-Methoxycarbonyl-2-pyrrolidinyl acetic acid (17). To $N$-methoxycarbonyl-L-proline 16 (0.77 g, 4.45 $\mathrm{mmol})$ in dry $\mathrm{CH}_{2} \mathrm{Cl}_{2}(16.0 \mathrm{~mL})$ was added $(\mathrm{COCl})_{2}(0.6$ $\mathrm{mL}$ ) and one drop of DMF at $0{ }^{\circ} \mathrm{C}$. The mixture was stirred for $4 \mathrm{~h}$ at room temperature. Solvent evaporation left a yellow oil which was dissolved in dry ether and then diazomethane was added at $0{ }^{\circ} \mathrm{C}$. The contents were stirred at $0{ }^{\circ} \mathrm{C}$ for $5 \mathrm{~h}$ followed by solvent removal which furnished the crude product. Dissolution of this product in dioxane (10.0 mL), followed by the addition of water $(10.0 \mathrm{~mL})$ and $\mathrm{Ag}_{2} \mathrm{O}(0.10 \mathrm{~g})$ and stirring at $90{ }^{\circ} \mathrm{C}$ for $6 \mathrm{~h}$ completed the reaction. Filtration over celite, solvent removal and purification by column chromatography over silica using $\mathrm{CH}_{2} \mathrm{Cl}_{2}$ and ethyl acetate (1.5:1) afforded $0.38 \mathrm{~g}$ (46\%) of 17 as light yellow oil. ${ }^{1} \mathrm{H} \mathrm{NMR}\left(300 \mathrm{MHz}, \mathrm{CDCl}_{3}\right): \delta 1.94$ (m, 3H, 2 H-4, 1 H-3), 2.14 (m, 1H, 1 H-3), 2.40 (dd, 1H, H1'), 3.03 (dd, 1H, H-1'), 3.40 (m, 2H, H-5), 3.69 (s, 3H, H-7), 4.19 (m, 1H, H-2), 8.76 (bs, 1H, OH).

Methyl (-)-(S)-N-methoxycarbonyl-2-pyrrolidinyl acetate (18). To $(S)-N$-methoxycarbonyl-2-pyrrolidinyl acetic acid $17(0.35 \mathrm{~g}, 1.87 \mathrm{mmol})$ in dry ether at $0{ }^{\circ} \mathrm{C}$, was added diazomethane in excess and the mixture was stirred for $1.5 \mathrm{~h}$ at this temperature. After, solvent removal, the crude product was purified by column chromatography over silica gel using petroleum ether and ethyl acetate (1.5:1) as eluent. The work-up yielded $0.38 \mathrm{~g}(100 \%)$ of 18 as light yellow oil. $[\alpha]_{\mathrm{D}}{ }^{25}-50.0\left(c 1.1, \mathrm{CH}_{2} \mathrm{Cl}_{2}\right) .{ }^{1} \mathrm{H} \mathrm{NMR}$ (300 MHz, $\left.\mathrm{CDCl}_{3}\right): \delta 1.91(\mathrm{~m}, 3 \mathrm{H}, 2 \mathrm{H}-4,1 \mathrm{H}-3), 2.11(\mathrm{~m}$, 1H, $1 \mathrm{H}-3$ ), 2.37 (dd, 1H, H-1') 2.98 (dd, 1H, H-1'), 3.43 (m, 2H, H-5), 3.68, 3.69 (2s, 3H, H-3'), 3.69 (s, 3H, H-7), 4.19 (m, 1H, H-2). $\left.{ }^{13} \mathrm{C} \mathrm{NMR} \mathrm{(75.5} \mathrm{MHz,} \mathrm{CDCl}_{3}\right): \delta 23.1$, 23.9 (C-4), 30.9, 31.7 (C-3), 38.5, 39.4 (C-1'), 46.7, 47.1 (C-5), 51.9 (C-3'), 52.5, 52.7 (C-7), 54.3, 54.9 (C-2), 155.7 (C-6), 172.2 (C-2').

(-)-(S)-N-Methoxycarbonyl-2-pyrrolidinyl propanone (6). Tebbe's reagent ( $2.88 \mathrm{~mL}, 0.5 \mathrm{~mol} \mathrm{~L}^{-1}$ in toluene) was added to ester $18(0.29 \mathrm{~g}, 1.44 \mathrm{mmol})$ dissolved in tetrahydrofuran $(3.0 \mathrm{~mL})$ at $0{ }^{\circ} \mathrm{C}$, and the mixture was stirred for $30 \mathrm{~min}$ at room temperature. Soon after, ether $(15.0 \mathrm{~mL})$ and two drops of $\mathrm{NaOH}$ ( 10\% aqueous solution) was added to it and stirred for an additional $20 \mathrm{~min}$. After this, 12 drops of an aqueous hydrochloric acid solution (1.0 mol L-1) was added and the contents stirred for $1.5 \mathrm{~h}$ at room temperature. Water $(30.0 \mathrm{~mL})$ addition to the flask, neutralization with $\mathrm{NaHCO}_{3}$, extration with dichloromethane ( $3 \times 30.0 \mathrm{~mL}$ ), drying the solvent over $\mathrm{Na}_{2} \mathrm{SO}_{4}$, filtration and solvent evaporation under reduced pressure gave an oil. Purification by liquid chromatography over silica gel using petroleum ether and ethyl acetate (1.5:1.0) provided pure $6(0.22 \mathrm{~g}, 83 \%)$ as light yellow oil. $[\alpha]_{\mathrm{D}}{ }^{25}-66.1\left(c 1, \mathrm{CH}_{2} \mathrm{Cl}_{2}\right) .{ }^{1} \mathrm{H} \mathrm{NMR}\left(300 \mathrm{MHz}, \mathrm{CDCl}_{3}\right): \delta$ 
1.28-1.34 (4t overlapping, $6 \mathrm{H}, \mathrm{J} 6.9 \mathrm{~Hz}$, aliph.- $\mathrm{CH}_{3}$ ), 1.45 1.83 (m, 4H, H-3, H-4), 2.43 (s, 1.5H, H-12), 2.44 (s, 1.5H, $\mathrm{H}-12$ ), 2.66 (dd, $0.5 \mathrm{H}, J 10.0 \mathrm{~Hz}, J 13.7 \mathrm{~Hz}, \mathrm{H}-1^{\prime}$ ), 3.01 (dd, $\left.0.5 \mathrm{H}, J 9.8 \mathrm{~Hz}, J 18.2 \mathrm{~Hz}, \mathrm{H}-1^{\prime}\right), 3.03-3.10$ (m, 1H, H-5), 3.18 (dd, $0.5 \mathrm{H}, J 4.5 \mathrm{~Hz}, J 13.7 \mathrm{~Hz}, \mathrm{H}-1^{\prime}$ ) , 3.39 (dd, $0.5 \mathrm{H}, J$ $3.1 \mathrm{~Hz}, J 18.2 \mathrm{~Hz}, \mathrm{H}-1^{\prime}$ ), 3.41-3.49 (m, 1H, H-5), 3.94-4.01 (m, 1H, H-2), 4.29 (q, $\left.4 \mathrm{H}, J 7.1 \mathrm{~Hz},-\mathrm{OCH}_{2}-\right), 4.50(\mathrm{~s}, 0.5 \mathrm{H}$, H-3'), 7.33 (d, 2H, J 7.9 Hz, H-8, H-10), 7.76 (d, 2H, J 8.2 $\mathrm{Hz}, \mathrm{H}-7, \mathrm{H}-11), 13.25$ (s, 0.5H, OH). Some carbons gave two peaks because the compound exists as rotamers at room temperature.

$N$-Methoxycarbonyl-2-pyrrolidinyl propanol-2 (3 and 4). To (-)-(S)-N-methoxycarbonyl-2-pyrrolidinyl propanone $6(0.21 \mathrm{~g}, 1.14 \mathrm{mmol})$ in methanol $(10.0 \mathrm{~mL})$ at $0{ }^{\circ} \mathrm{C}$ was added $\mathrm{NaBH}_{4}(86 \mathrm{mg}, 2.27 \mathrm{mmol})$ under stirring and the agitation continued for $1 \mathrm{~h}$ more maintaining this temperature. After this, an aqueous solution of $\mathrm{HCl}$ (2.0 $\mathrm{mL}, 1.0 \mathrm{~mol} \mathrm{~L}^{-1}$ ) was added to it and stirred for an additional $10 \mathrm{~min}$. Neutralization of this solution with aqueous $\mathrm{NaHCO}_{3}$, extraction with dichloromethane and work-up yielded two diastereoisomers which were separated by column chromatography over silica gel using petroleum ether and ethyl acetate (1:1), both as light yellow oils. The yields of $\mathbf{3}(125 \mathrm{mg})$ and $\mathbf{4}(66 \mathrm{mg})$ together turned out to be $90 \%$. Compound 3: $R_{f} 0.36$ (petroleum ether:EtOAc, $1: 1),[\alpha]_{\mathrm{D}}{ }^{25}-73.5\left(c 1.13, \mathrm{CH}_{2} \mathrm{Cl}_{2}\right) .{ }^{1} \mathrm{H} \mathrm{NMR}(300 \mathrm{MHz}$, $\left.\mathrm{CDCl}_{3}\right): \delta 1.14\left(\mathrm{~d}, 3 \mathrm{H}, J 6.0 \mathrm{~Hz}, \mathrm{H}^{\prime} 3^{\prime}\right), 1.35-1.96(\mathrm{~m}, 6 \mathrm{H}, 2$ H-1', 2 H-3, 2 H-4), 3.31 (m, 2H, H-5), 3.62 (s, 3H, H-7), 3.79 (m, 1H, H-2), 3.98 (m, $1 \mathrm{H}, \mathrm{H}-2)$ ). ${ }^{13} \mathrm{C} \mathrm{NMR}(75.5 \mathrm{MHz}$, $\left.\mathrm{CDCl}_{3}\right): \delta 24.1(\mathrm{C}-4), 24.4\left(\mathrm{C}^{\prime} 3^{\prime}\right), 31.8(\mathrm{C}-3), 44.9\left(\mathrm{C}^{\prime} \mathbf{1}^{\prime}\right)$, 46.4 (C-5), 52.6 (C-7), 56.1 (C-2), $66.3(\mathrm{C}-2$ '), 156.4 (C-6). Compound 4: $R_{f} 0.44$ (petroleum ether:EtOAc, $\left.1: 1\right),[\alpha]_{\mathrm{D}}^{25}$ $-3.0\left(c 0.72, \mathrm{CH}_{2} \mathrm{Cl}_{2}\right)$. Lit: ${ }^{3}[\alpha]_{\mathrm{D}}{ }^{25}-2.0\left(c 0.7, \mathrm{CH}_{2} \mathrm{Cl}_{2}\right) .{ }^{1} \mathrm{H}$ NMR (300 MHz, CDCl $): \delta 1.18$ (d, 3H, $J 6.4 \mathrm{~Hz}, \mathrm{H}-3$ '), 1.36-1.62 (m, 3H, $1 \mathrm{H}-3,2 \mathrm{H}-4), 1.90-2.04$ (m, 3H, 2 H-1', $1 \mathrm{H}-3), 3.38$ (m, 2H, H-5), 3.65-3.83 (m, 1H, H-2), 3.71 (s, $3 \mathrm{H}, \mathrm{H}-7), 4.22$ (m, 1H, H-2'), 4.77 (bs, $1 \mathrm{H}, \mathrm{OH}) .{ }^{13} \mathrm{C} \mathrm{NMR}$ $\left(75.5 \mathrm{MHz}, \mathrm{CDCl}_{3}\right): \delta 22.9\left(\mathrm{C}-3^{\prime}\right), 23.9(\mathrm{C}-4), 31.5(\mathrm{C}-3)$, 45.8 (C-1'), 46.6 (C-5), 53.0 (C-2), 55.0 (C-7), 64.0 (C-2), 157.9 (C-6).

\section{Supplementary Information}

Crystallographic data (excluding structure factors) for racemic $\mathbf{2 a}, \mathbf{2 b}$ reported in this paper have been deposited with the Cambridge Crystallographic Data Centre as supplementary publication no. CCDC 244859. Copies of the data can be obtained, free of charge via www.ccdc.cam.ac.uk/conts/retrieving.html (or from the Cambridge Crystallographic Data Centre, CCDC, 12 Union Road, Cambridge CB2 1EZ, UK ; fax: +44 1223 336033; or e-mail: deposit@ccdc.cam.ac.uk).

\section{Acknowledgments}

The authors express their gratitude to both CAPES and CNPq of Brazil and CNRS (France) for financial help. One of us (MJeSilva) is thankful to CAPES/COFECUB for a fellowship. We would like to thank Dr. Bogdan Doboszewski for his nice suggestions at the initial stage of this work. We also thank Dr. Alain Thozet and Dr. Monique Perrin, Laboratoire de Cristallographie, Université Claude Bernard Lyon 1, Villeurbanne, France, for obtaining the crystallographic data.

\section{References}

1. Shono, T.; Matsumura, Y.; Tsubata, K.; J. Am. Chem. Soc. 1981, 103, 1172.

2. Shono, T.; Matsumura, Y.; Tsubata, K.; Uchida, K.; J. Org. Chem. 1986, 51, 2590.

3. Louis, C.; Hootelé, C.; Tetrahedron: Asymmetry 1997, 8, 109.

4. Pinder, A. R.; Nat. Prod. Rep. 1992, 17.

5. O'Hagan, D.; Nat. Prod. Rep. 2000, 17, 435.

6. Bunce, R. A.; Allison, J. C.; Synth. Commun. 1999, 29, 2175.

7. Tebbe, F. N.; Parshall, G. W.; Reddy, G. S.; J. Am. Chem. Soc. 1978, 100, 3611.

8. Busson, R.; Vanderhaeghe, H.; J. Org. Chem. 1978, 43, 4438.

9. Galinovsky, F.; Bianchetti, G.; Vogl, O.; Monatsh. Chem. 1953, 84, 1221.

10. Ramachandran, J.; Nature 1965, 206, 927.

11. Schön, I.; Chem. Rev. 1984, 84, 287.

12. Krapcho, A. P.; Synthesis 1982, 805.

13. Garcia, J. G.; Fronczek, F. R.; McLaughlin, M. L.; Acta Crystallogr., Sec.C-Crystal Structure Commum. 1991, 47, 1989.

14. Irie, H.; Nakanishi, H.; Fujii, N.; Mizuno, Y.; Fushimi, T.; Funakoshi S.; Yajima, H.; Chem. Lett. 1980, 705.

15. Cassal, J. -M.; Fürst, A.; Meier, W.; Helv. Chim. Acta 1976, 59, 1917. 